\title{
Mineralogical and geochemical study of Lake Dojran sediments (Republic of Macedonia)
}

\author{
Nastja Rogan Šmuc a,*, Todor Serafimovski ${ }^{\text {b }}$, Tadej Dolenec ${ }^{a}$, Matej Dolenec ${ }^{\text {a }}$, Petra Vrhovnik ${ }^{\text {a }}$, \\ Mirijam Vrabec ${ }^{a}$, Radojko Jačimovićc ${ }^{c}$, Vesna Logar Zorn ${ }^{\mathrm{d}}$, Darja Komar ${ }^{\mathrm{a}}$ \\ a Faculty of Natural Sciences and Engineering, University of Ljubljana, Department of Geology, Aškerčeva 12, 1000 Ljubljana, Slovenia \\ b Faculty of Natural and Technical Sciences, "Goce Delčev" University, Goce Delčev 89, MK-2000 Štip, Republic of Macedonia \\ c Institute Jožef Štefan, Jamova cesta 39, 1000 Ljubljana, Slovenia \\ ${ }^{\mathrm{d}}$ Ministry of Agriculture and the Environment, Slovenian Nuclear Safety Administration, Litostrojska cesta 54, 1000 Ljubljana, Slovenia
}

\section{A R T I C L E I N F O}

\section{Article history:}

Received 9 December 2012

Accepted 20 December 2014

Available online 3 January 2015

\section{Keywords:}

Mineralogy

Geochemical composition

Enrichment factor

Lake Dojran sediments

Balneotherapy

Republic of Macedonia

\begin{abstract}
A B S T R A C T
In this study the mineralogical and geochemical characteristics of Lake Dojran surficial $(0-5,5-10,10-15 \mathrm{~cm})$ sediments were studied in order to determine their suitability for use as potential raw material in balneotherapeutic treatments. X-ray powder diffraction (XRD) and inductively coupled plasma mass spectrometry (ICP-MS) analyses were performed, and thereupon chemical index of alteration (CIA) and enrichment factor (EF) values were calculated.

The XRD results revealed close association of sediment mineralogy with the prevailing metamorphic, volcanic and igneous rocks of the region surrounding Lake Dojran. CIA values of around $67 \%$ suggest a moderate degree of weathering in the lake catchment area.

According to the EF value results, surficial Lake Dojran sediments are little enriched with $\mathrm{Co}, \mathrm{Cr}, \mathrm{Cu}, \mathrm{Pb}$, and $\mathrm{Zn}$, moderately enriched with $\mathrm{Au}, \mathrm{Ni}$ and $\mathrm{Sb}$, moderately severely enriched with $\mathrm{Au}$, severely enriched with $\mathrm{Sb}$ and very severely enriched with As. This elemental enrichment likely originates from various different geogenic (geological background and polymetallic mineralization) and anthropogenic (tourism, traffic, coatings, untreated wastewater discharge and agrochemicals) sources. The abundances of the major elements, trace elements and rare earth elements (REEs) were almost constant, changing very little throughout the surficial $(0-5,5-10,10-$ $15 \mathrm{~cm}$ ) sediments. Comparison of sediment trace element concentrations with consensus-based threshold effect concentration (TEC) and probable effect concentration (PEC) values showed that lake biota may be under threat of contamination with As, $\mathrm{Cu}$ and $\mathrm{Ni}$.

Given the present results, we cannot recommend/confirm the application of Lake Dojran dark mud sediment in balneotherapeutic treatments.
\end{abstract}

(C) 2015 Elsevier B.V. All rights reserved.

\section{Introduction}

Lakes represent some of the most versatile and unique ecosystems on Earth, but unfortunately they are also readily affected by various anthropogenic activities (Oyewale and Musa, 2006). Since lakes are mostly closed or nearly closed systems, lake sediments can be treated as the final recipients of the results of anthropogenic activity within the lakebasin area. Consequently, they operate as both carriers and storage sinks for contaminants, thus reflecting the history of long-term geogenic or anthropogenic impacts (Bibi et al., 2007; Kumar Das et al., 2008; Maltby, 1992; Singh et al., 2005).

Contaminants, especially trace elements and metalloids, are a group of pollutants with high ecological significance in aquatic ecosystems. Trace elements do not exist in solid phases in water bodies, instead

\footnotetext{
* Corresponding author. Tel.: + 3861470 4500; fax: + 38614704560.

E-mail address: nastja.rogan@guest.arnes.si (N. Rogan Šmuc).
}

accumulating mainly in suspended particulates or in sediment material (Ghrefat and Yusuf, 2006; Kabata-Pendias and Pendias, 2001; Khaled et al., 2006). Metals/metalloids found in aquatic sediments may be natural or man-made in origin; weathering of soils/rocks and atmospheric deposition are known geogenic sources, while the discharge of agricultural, municipal, residential and industrial waste products from surrounding environments into water bodies has been determined as the main anthropogenic source (Demirak et al., 2006; Ghrefat and Yusuf, 2006; Khaled et al., 2006; Singh et al., 2005). Over the last few decades, a number of geochemical studies have focused on lake sediments with the aim of evaluating the extent of environmental contamination (e.g. Arnason and Fletcher, 2003; Aysegül et al., 2010; Fan et al., 2002; Gramatica et al., 2006; Tylmann et al., 2011).

Lake Dojran, located in the SE of the Republic of Macedonia, is lying on the border between Macedonia and the Republic of Greece. Geothermal processes and polymetallic mineralization in the Lake Dojran catchment area could potentially have conferred uniquely 
beneficial properties on the dark mud lake sediments, possibly such that the latter could be perceived as having healing powers (i.e. peloids) (Stojanov and Micevski, 1989). Consequently, dark fine-grained lake sediments are locally regarded as peloids, which are widely considered to have numerous balneotherapeutic benefits for humans. Peloids, finegrained sediments, mixture of organic and inorganic materials, are often used for mud baths and cataplasms, for recovering muscle-bone-skin pathologies and for applications in wellness and relax activities (Veniale et al., 2007). Recent investigations showed the necessity of studying the geochemical composition of peloids used in balneotherapy due to their possible toxicity and resorption through the skin into human body (Karakaya et al., 2010; Miko et al., 2008; Rebelo et al., 2011; Tateo et al., 2009; Veniale et al., 2007). Local inhabitants and tourists are using them for decades as mud baths and skin coats. Unfortunately, information regarding the geochemical properties and environmental status of Lake Dojran sediments (peloids) is very scarce and unconfirmed (Stojanov et al., 1997).

In this context, the main objectives of the research were as follows:

- to evaluate the content and distribution of major, trace and rare earth elements in Lake Dojran sediments,

- to define the anthropogenic versus natural contribution to lake sediment trace elements, and

- to determine Lake Dojran sediment potentials for application in balneotherapy.

\section{Materials and methods}

\subsection{Description of the study site and geological characteristics}

Lake Dojran, a natural wonder with a rich cultural heritage, is located in the SE of the Republic of Macedonia, on the border between Republic of Macedonia and the Republic of Greece (Fig. 1). Lying at an altitude of
148 masl., the lake has a mean depth of $6.7 \mathrm{~m}$ and a surface area of $43.10 \mathrm{~km}^{2}, 66 \%$ of which belongs to the territory of the Republic of Macedonia. Lake catchment area occupies an area at around $120 \mathrm{~km}^{2}$ (mainly from the $\mathrm{N}$ and NE, where the Bjelasica mountains are situated). Lake Dojran is elliptical in shape, with a N-S elongation $8.9 \mathrm{~km}$ in length and $7 \mathrm{~km}$ in width. In the northern part of the lake there are a few small groundwater sources. Due to high water outflow (irrigation system) in the south, the Macedonian government decided to build water feeding system into the lake, which consists of wells system in the river of Vardar (near the city of Valandovo), $20 \mathrm{~km}$ away from the Lake Dojran. All of them are combined into one inflow with a capacity of $650-800$ l/s, near the city of Novi Dojran. The Dojran area was and still is an important agricultural and tourist province (Stojanov et al., 1997). Agricultural and tourism activities around the lake resulted in enhanced agrochemicals, landfill leachate and municipality discharges into the lake and increased traffic effects.

Lake Dojran is situated in the Dojran graben, the tectonic border between metamorphic rocks of the Serbo-Macedonian Massif and volcanic/sedimentary rocks of the Vardar zone. Development of the Dojran graben is related to the neotectonic movement during the Neogene which was followed by volcanic and post-volcanic activities. Precambrian and Palaeozoic metamorphic rocks (gneisses, shales, amphibolites and marbles) of the Serbo-Macedonian Massif currently comprise the NE of the study site, together with intrusions of Bjelasica granites and basic intrusions of gabbro. Serpentinites can be found in the eastern part of the massif, while the border of the SerboMacedonian Massif with the Vardar zone is composed of granite porphyries, metarhyolites and metamorphic pyroclastites. The region SW of the lake is represented by four main lithologies: Permian to Triassic metamorphic sedimentary and volcanic rocks, and Tertiary Q conglomerates and volcanic rocks (trachytes and rhyolites) (Fig. 2). Polymetallic mineralization with chalcopyrite, pyrite, bornite and gold is located in the contact between muscovite gneisses and amphibolite shales,

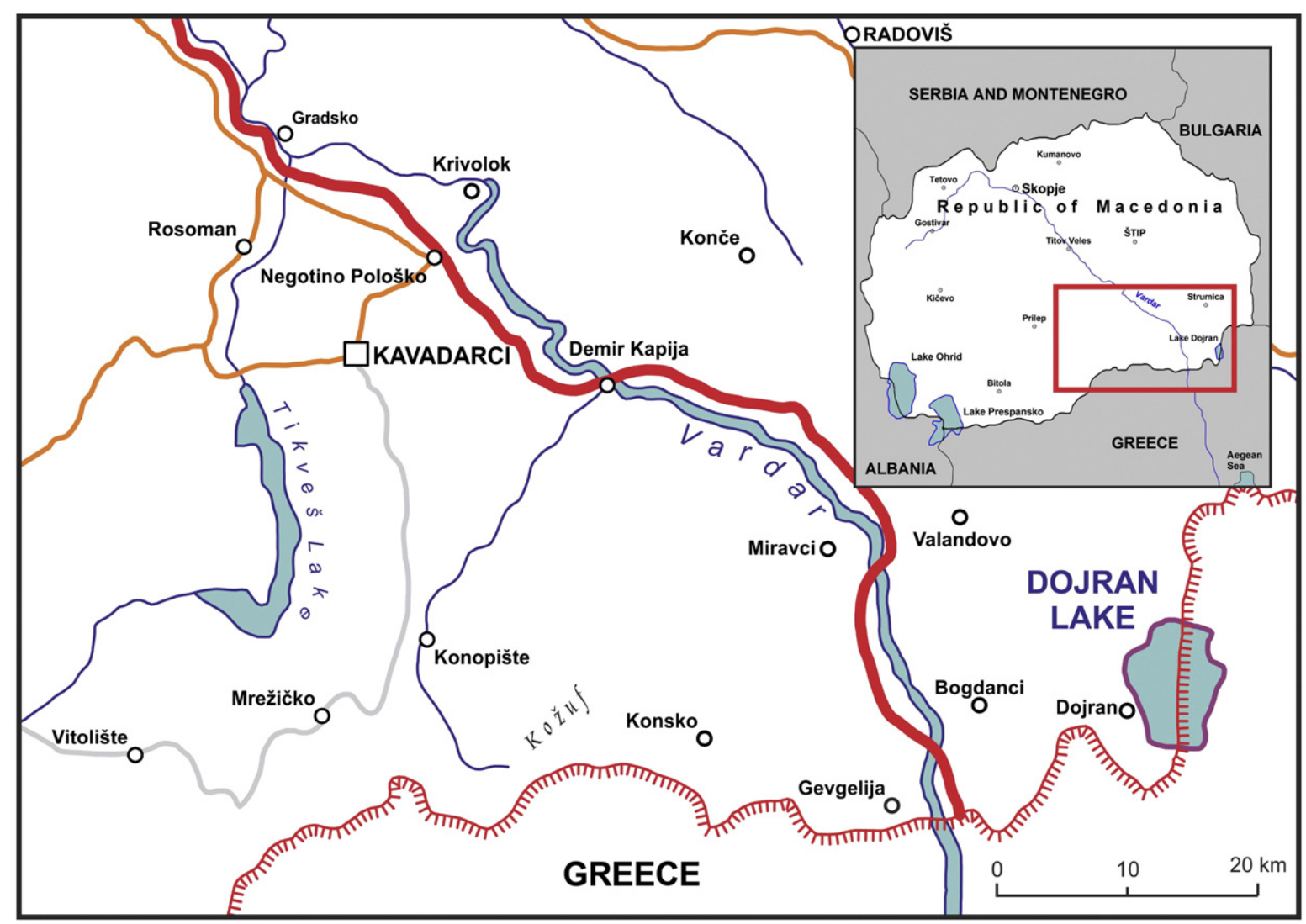

Fig. 1. Study area (Lake Dojran region, Republic of Macedonia). 



Fig. 2. Geological composition of research area.

whereas a pyrite-arsenopyrite-gold polymetallic association forms part of basic rocks (Stojanov and Micevski, 1989).

Granulometric analysis showed that Lake Dojran sediments were generally dominated by fine-grained fractions $(0.014 \mathrm{~mm})$, with only $4.10 \%$ sand compared with $71.50 \%$ silt and $24.40 \%$ clay (Stojanov et al., 1997 ).

Complex magmatic intrusions, as well as volcanic and post-volcanic processes occurred along the Vardar zone fault structures, influencing the evolution of several palaeogeothermal events and polymetallic mineralization beneath the lake floor, which in turn provided conditions beneficial to the intense development of lake flora and fauna.

\subsection{Sampling}

Sampling of lake sediments was conducted in the autumn of 2005 (Fig. 3); the six sampling locations (D1, D2, D3, D4, D5 and D6) across Lake Dojran (Republic of Macedonia) are shown in Fig. 3. Samples were collected with the push plastic corers (tube $20 \mathrm{~cm}$ long with a $10 \mathrm{~cm}$ internal diameter), tightly packed into pre-cleaned plastic bags and stored in the laboratory at $4{ }^{\circ} \mathrm{C}$. Samples were sectioned into three $5 \mathrm{~cm}$ depth slices: $0-5 \mathrm{~cm}$ (6 locations), $5-10 \mathrm{~cm}$ (2 B locations) and $10-15 \mathrm{~cm}$ (2 C locations). Prevailingly composed of sand, silt and clay, the sediment samples were dried at $50{ }^{\circ} \mathrm{C}$ for $48 \mathrm{~h}$, before being sieved through a $0.315 \mathrm{~mm}$ polyethylene sieve in order to remove molluscan remains and other organic debris. Finally, the samples were homogenized using a mechanical agate grinder into a fine powder $(<63 \mu \mathrm{m})$ for subsequent analyses.

\subsection{Methods}

An amount of sample was roasted at $1000{ }^{\circ} \mathrm{C}$ to detect the loss on ignition (LOI), while sediment $\mathrm{pH}$ was measured in deionized water with a $1: 2$ soil/solution ratio after equilibration for $15 \mathrm{~min}$ (US EPA, 1998). Total carbon content were analyzed by LECO carbon-sulfur analyzer in a certified commercial Canadian laboratory (Acme Analytical Laboratories).

In order to define detailed mineralogical and elemental characteristics of sediment samples, X-ray powder diffraction (XRD) and ICP analyses were employed.

The mineral composition of the sediment samples was determined via X-ray powder diffraction using a Philips PW3710 X-ray diffractometer equipped with $\mathrm{Cu} K \alpha$ radiation and a secondary graphite monochromator. Data were collected at $40 \mathrm{kV}$ and a current of $30 \mathrm{~mA}$ in a range from 2 to $70^{\circ} 2 \theta$, at a speed of $3.4 \mathrm{o} / \mathrm{min}$.

All surficial sediments were measured for their detailed geochemical composition in an accredited commercial Canadian laboratory (Acme Analytical Laboratories, Vancouver, B.C., Canada). Total abundances of major elements, rare earth and trace elements were determined by ICP-emission spectrometry following lithium metaborate/tetraborate fusion and dilute nitric digestion. In addition, a separate sample was digested in aqua regia and analyzed via ICP mass spectrometry to report on precious and base metal content.

Duplicate samples and blanks were also included to ensure the accuracy of all analytical methods employed. Analytical precision and accuracy were better than $\pm 5 \%$ for the investigated elements.

\subsection{Statistical analysis}

To assess the elemental associations and origins of the analyzed elements in the Lake Dojran sediments, Pearson R correlation analyses were applied to all samples. Critical values of the correlation coefficient (r) 0.81 at $\mathrm{p} \leq 0.05$ were considered highly significant. Principal component analysis (PCA) based on a covariance matrix was used to examine variation in the measured parameters between locations. The basic statistical parameters for each element and the statistical calculations mentioned above were performed using the software programs Statistica VII and Grapher 8.0. 


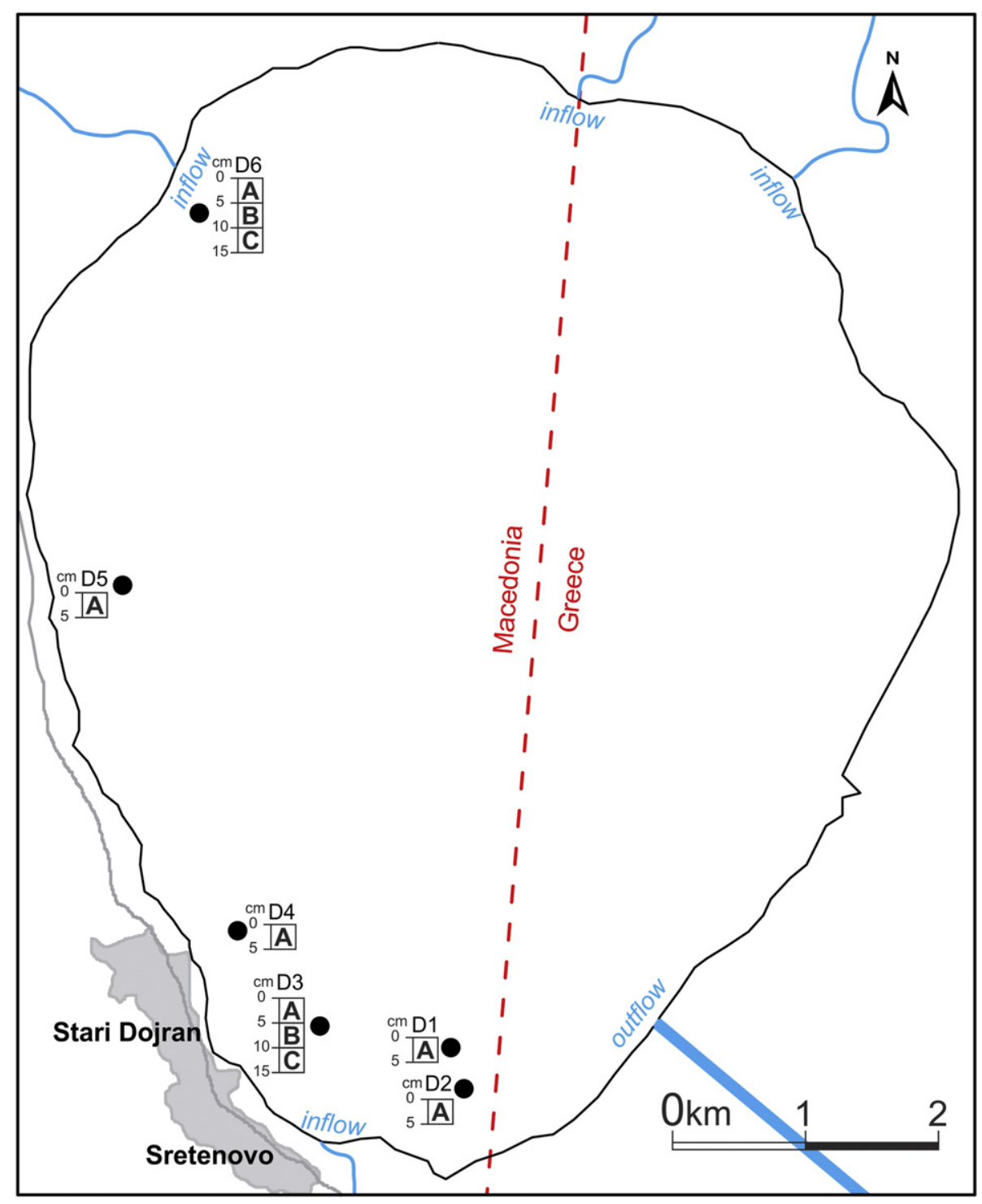

Fig. 3. Sampling locations across Lake Dojran.

\subsection{Enrichment factor}

The enrichment factor (EF) is a useful indicator/index reflecting the level of sediment environmental contamination. It was employed to evaluate possible anthropogenic input of metals/metalloids to Lake Dojran sediments (Kemp et al., 1976; Van Metre and Callender, 1997), calculated as:

$\mathrm{EF}=(\mathrm{M} / \mathrm{Al})_{\text {sample }} /(\mathrm{M} / \mathrm{Al})_{\text {crust }}$

where $M_{\text {sample }}$ and $M_{\text {crust }}$ are the levels of the investigated metals/ metalloids ( $\mathrm{Au}, \mathrm{As}, \mathrm{Co}, \mathrm{Cr}, \mathrm{Cu}, \mathrm{Ni}, \mathrm{Pb}, \mathrm{Sb}$ and $\mathrm{Zn}$ ) in the sediment samples and uncontaminated crust material, respectively; and $\mathrm{Al}_{\text {sample }}$ and $\mathrm{Al}_{\text {crust }}$ are the levels of $\mathrm{Al}$ in sediment samples and uncontaminated crust material, respectively. Metal to aluminium ratios such as these are widely adopted, presumably because the concentrations of weathering products and their parent materials are generally comparable. Aluminium is also the normalizing element, levels of which are assumed not to be enriched owing to local contamination (Chen et al., 2007). In this study, baseline values for $\mathrm{M}_{\text {crust }}$ and $\mathrm{Al}_{\text {crust }}$ were adopted from Taylor and McLennan (1995).
2.6. Chemical index of alteration (CIA)

To evaluate the extent of weathering of feldspars relative to unaltered rocks from the catchment area, the chemical index of alteration (CIA) was defined as (Nesbitt and Young, 1982):

$\mathrm{CIA}=\left(\mathrm{Al}_{2} \mathrm{O}_{3} /\left(\mathrm{Al}_{2} \mathrm{O}_{3}+\mathrm{CaO} *+\mathrm{Na}_{2} \mathrm{O}+\mathrm{K}_{2} \mathrm{O}\right)\right) \times 100$

Table 1

Loss on ignition (LOI), C and pH data for Lake Dojran surficial sediments: 0-5 cm (D1, D2, D3, D4, D5, and D6), 5-10 cm (D3 B, D6 B) and 10-15 cm (D6 B, D6 C).

\begin{tabular}{lrll}
\hline Sample & LOI $(\%)$ & $\mathrm{C}(\mathrm{g} / \mathrm{kg})$ & $\mathrm{pH}$ \\
\hline D1 & 8.26 & 15.5 & 5.8 \\
D2 & 8.13 & 14.2 & 6.0 \\
D3 & 13.21 & 30.5 & 6.2 \\
D4 & 33.67 & 88.5 & 6.4 \\
D5 & 19.00 & 52.5 & 6.8 \\
D6 & 8.55 & 12.7 & 7 \\
D3 B & 16.93 & 44.5 & 5.8 \\
D3 C & 19.00 & 47.0 & 5.9 \\
D6 B & 8.53 & 14.3 & 6 \\
D6 C & 9.81 & 16.8 & 6.3
\end{tabular}


Table 2

Major element concentrations of Lake Dojran surficial sediments together with Lake Dojran surficial sediments $(0-5 \mathrm{~cm})$

\begin{tabular}{lllllllllll}
\hline El. $(\mathrm{g} / \mathrm{kg}) /$ sample & $\mathrm{Si}$ & $\mathrm{Al}$ & $\mathrm{Fe}$ & $\mathrm{Ca}$ & $\mathrm{Mg}$ & $\mathrm{K}$ & $\mathrm{Na}$ & $\mathrm{Mn}$ & $\mathrm{P}$ & $\mathrm{Ti}$ \\
\hline D1 & 270.0 & 79.0 & 47.0 & 37.5 & 8.2 & 22.4 & 6.8 & 1.1 & 0.8 & 4.3 \\
D2 & 270.0 & 79.0 & 43.0 & 42.2 & 8.1 & 22.3 & 7.4 & 0.8 & 0.5 & 4.4 \\
D3 & 241.0 & 60.0 & 29.0 & 90.5 & 5.1 & 17.7 & 7.6 & 0.7 & 0.8 & 3.3 \\
D4 & 70.7 & 30.0 & 16.9 & 271.6 & 4.0 & 9.0 & 3.9 & 0.5 & 0.1 & 1.6 \\
D5 & 220.4 & 75.0 & 45.1 & 44.9 & 12.7 & 21.0 & 8.6 & 1.0 & 1.2 & 4.2 \\
D6 & 240.2 & 88.0 & 60.6 & 36.2 & 21.4 & 15.0 & 18.6 & 1.6 & 0.7 & 6.2 \\
\hline
\end{tabular}

where $\mathrm{CaO}^{*}$ is the amount of $\mathrm{CaO}$ incorporated in the silica fraction of rocks. Many studies involving the use of the CIA adopt the correction method proposed by McLennan (1993), which suggests that CaO* can be estimated by assuming reasonable $\mathrm{Ca} / \mathrm{Na}$ ratios in silicate material. If the $\mathrm{CaO}$ molar content is less than that of $\mathrm{Na}_{2} \mathrm{O}$, the measured $\mathrm{CaO}$ content can be used for $\mathrm{CaO}^{*}$, whereas if the $\mathrm{CaO}$ molar content is greater than that of $\mathrm{Na}_{2} \mathrm{O}, \mathrm{CaO}^{*}$ is assumed to be equivalent to $\mathrm{Na}_{2} \mathrm{O}$.


The average upper continental crust denotes a CIA value of 47 (Taylor and McLennan, 1995). CIA values of 45-55 therefore indicate no/very weak weathering conditions, while a value of 100 possesses extreme weathering, manifested by the presence of typical weathering minerals such as kaolinite, illite, chlorite, gibbsite, etc.

\section{Results and discussion}

\subsection{Physico-chemical characteristics of lake sediments}

The sampled lake sediments were characterized by an LOI content of less than 33\%; the highest value was detected at location D4, while slight variability was observed between the northern and southern parts of the lake (Table 1). A strong and statistically significant correlation was found between LOI and total C. Sediment $\mathrm{pH}$ values ranged between 5.8 and 7 (Table 1).
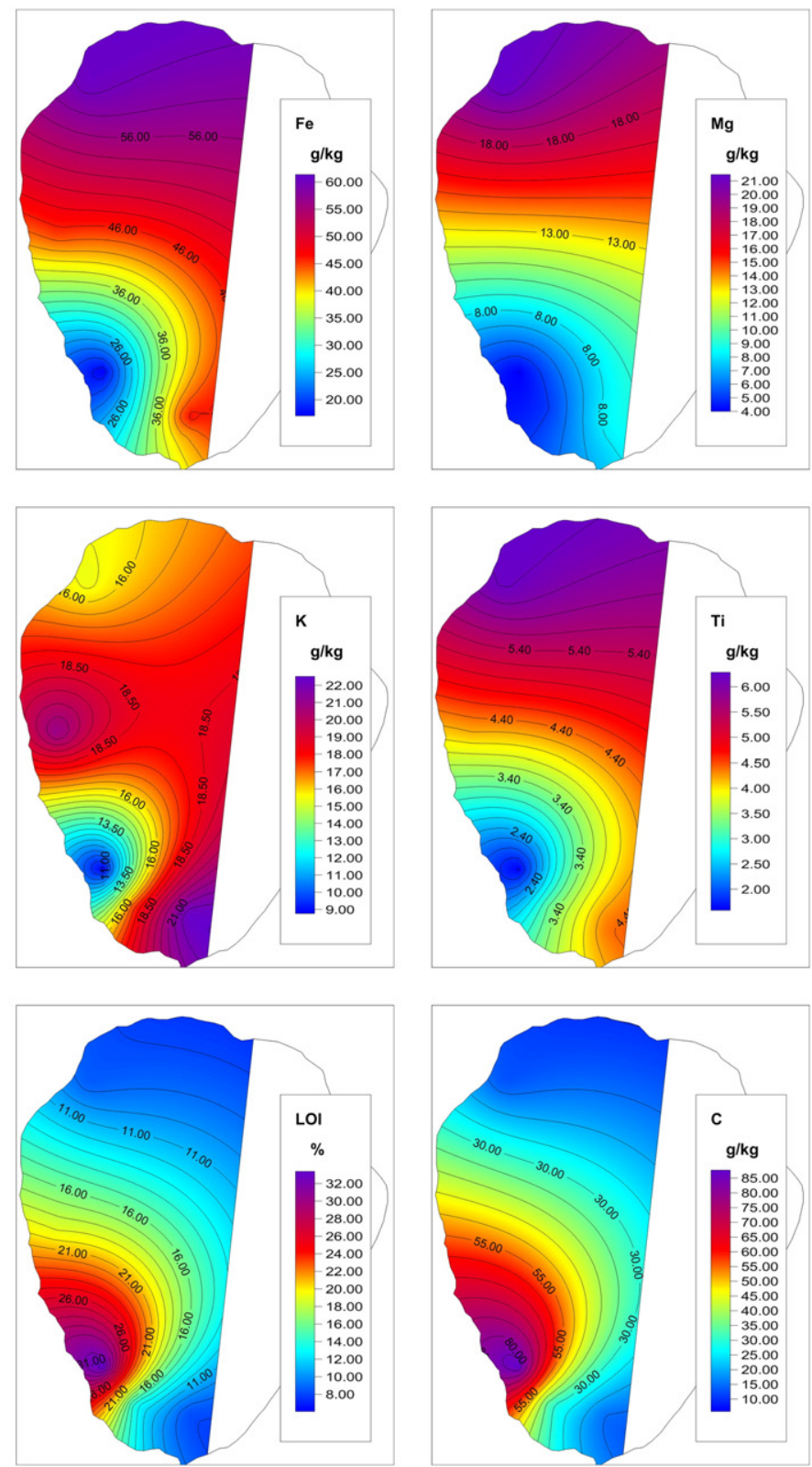

Fig. 4. Spatial distribution of major elements, LOI and C (0-5 cm depth). 
Table 3

Pearson correlation coefficient between major elements (0-5 cm depth).

\begin{tabular}{|c|c|c|c|c|c|c|c|c|c|c|}
\hline & \multicolumn{10}{|c|}{ Marked correlation are significant at $\mathrm{p}<0.05$} \\
\hline & $\mathrm{Si}$ & $\mathrm{Al}$ & $\mathrm{Fe}$ & $\mathrm{Mn}$ & $\mathrm{Mg}$ & $\mathrm{Ca}$ & $\mathrm{Na}$ & K & $\mathrm{Ti}$ & $\mathrm{P}$ \\
\hline $\mathrm{Si}$ & 1.00 & 0.88 & 0.70 & 0.49 & 0.33 & -0.94 & 0.38 & 0.87 & 0.73 & -0.47 \\
\hline $\mathrm{Al}$ & 0.88 & $\overline{1.00}$ & 0.95 & 0.80 & 0.70 & $\overline{-0.97}$ & 0.66 & $\overline{0.76}$ & 0.94 & -0.33 \\
\hline $\mathrm{Fe}$ & $\overline{0.70}$ & 0.95 & $\overline{1.00}$ & 0.94 & 0.87 & $\overline{-0.85}$ & 0.81 & 0.55 & $\overline{0.98}$ & -0.22 \\
\hline Mn & 0.49 & $\overline{0.80}$ & 0.94 & $\overline{1.00}$ & $\overline{0.95}$ & $\overline{-0.66}$ & 0.92 & 0.24 & $\overline{0.93}$ & -0.15 \\
\hline $\mathrm{Mg}$ & 0.33 & 0.70 & $\overline{0.87}$ & 0.95 & $\overline{1.00}$ & -0.56 & $\overline{0.95}$ & 0.12 & $\overline{0.88}$ & -0.01 \\
\hline $\mathrm{Ca}$ & -0.94 & -0.97 & $-\overline{0.85}$ & $-\overline{0.66}$ & -0.56 & 1.00 & $-\overline{0.53}$ & -0.86 & $-\overline{\mathbf{0 . 8 5}}$ & 0.26 \\
\hline $\mathrm{Na}$ & 0.38 & 0.66 & 0.81 & 0.92 & 0.95 & -0.53 & 1.00 & 0.03 & 0.87 & -0.18 \\
\hline K & 0.87 & 0.76 & 0.55 & $\overline{0.24}$ & $\overline{0.12}$ & -0.86 & 0.03 & 1.00 & $\overline{0.50}$ & -0.21 \\
\hline $\mathrm{Ti}$ & $\overline{0.73}$ & 0.94 & 0.98 & 0.93 & 0.88 & $\overline{-0.85}$ & 0.87 & 0.50 & 1.00 & -0.31 \\
\hline $\mathrm{P}$ & -0.47 & $-\overline{0.33}$ & $-\overline{0.22}$ & $-\overline{0.15}$ & $-\overline{0.01}$ & 0.26 & $-\overline{0.18}$ & -0.21 & -0.31 & 1.00 \\
\hline
\end{tabular}

\subsection{Mineralogy of lake sediments}

The exposed and underlying lithologies of the Dojran region are predominantly composed of gneisses, shales, amphibolites, marbles, granite porphyries, metarhyolites, metamorphic pyroclastites and Bjelasica granites, as well as the other metamorphic, sedimentary and volcanic rocks (Stojanov and Micevski, 1989). Surficial sediment samples of mineralogy of the lake are thus closely related to these prevailing rocks. The mineralogical assemblage of the lake sediments is mostly comprised of quartz, feldspars (orthoclase, microcline and albite), clay minerals (kaolinite and montmorillonite/illite), calcite and micas (biotite, muscovite and lepidolite), along with minor augite and hornblende. Traces of zircon, epidote, glaucofane and goethite were found only sporadically.

No significant changes in the predominant pattern of sediment mineral composition were observed throughout the investigated area.

\subsection{Major elements in surficial lake sediments $(0-5 \mathrm{~cm})$}

Major element concentrations in Lake Dojran sediments are summarized in Table 2.

More than $65 \%$ of major elements in almost all surficial sediment samples (D1, D2, D3, D5 and D6) were accounted for Si-Al-Fe components, likely reflecting a relatively high proportion of quartz, feldspars, clay minerals and micas present in these sediments. The measured $\mathrm{Ca}$ and $\mathrm{Mg}$ concentrations (ranging approximately from 36.2 to $271.6 \mathrm{~g} / \mathrm{kg} \mathrm{Ca}$ and 0.4 to $2.14 \mathrm{~g} / \mathrm{kg} \mathrm{Mg}$ in samples D1, D2, D3, D5 and D6) could reflect the presence of feldspars, montmorillonite, micas, augite and/or hornblende, as well as low amounts of calcite. In contrast, Ca is the main component $(271.6 \mathrm{~g} / \mathrm{kg}$ ) of sample D4, indicating increased levels of calcite and/or aragonite mollusk shells defining an authigenic source of $\mathrm{Ca}^{2+}$. Alkalis ( $\mathrm{K}$ and $\mathrm{Na}$, respectively) were found in all samples, probably bonded to feldspars, montmorillonite/illite, micas and/ or augite. Mn concentrations ranged from 0.5 to $1.6 \mathrm{~g} / \mathrm{kg}$, while phosphorous $(\mathrm{P})$ content varied between 0.1 and $1.2 \mathrm{~g} / \mathrm{kg}$, with no significant variation observed among the analyzed samples. Titanium (Ti) levels ( 1.6 to $6.2 \mathrm{~g} / \mathrm{kg}$ ) are likely connected with the presence of minerals such as micas, augite and/or hornblende.

Analysis of the spatial distribution of elements (Fig. 4) revealed the following patterns: $\mathrm{Al}$ and $\mathrm{Fe}$ abundances were highest on the NW side of the lake; the highest $\mathrm{Si}$ and $\mathrm{K}$ values were at the $\mathrm{N}$ and $\mathrm{S}$ ends of the lake; Ca distribution showed the opposite pattern to $\mathrm{Si}$; $\mathrm{Mg}, \mathrm{Na}$, $\mathrm{Mn}$ and Ti content decreased from $\mathrm{N}$ to $\mathrm{S}$; the highest $\mathrm{P}$ concentrations were dominated in the W and SW parts of Lake Dojran. These spatial distribution patterns are closely associated with the surrounding and underlying lithologies of the wider Dojran region.

CIA values (Nesbitt and Young, 1982) of around 67\% show that the rocks of the lake catchment area undergo moderate degree of weathering.

Pearson correlation analysis (Table 3 ) pointed out the significantly positive correlation between $\mathrm{Si}$ and both $\mathrm{Al}$ and $\mathrm{K}$, indicating the association of Si with feldspars, clay minerals and/or micas. The zero to highly significant negative correlation observed between Si and other elements (Fe, Mn, Mg, Ca, Na, Ti and P) suggests their removal from silicate phases during weathering. The highly positive correlation of Al with Fe and Ti; Fe with $\mathrm{Mg}$ and Ti; Mn with $\mathrm{Mg}$, Na and Ti; $\mathrm{Mg}$ with $\mathrm{Na}$ and $\mathrm{Ti}$, and finally that of $\mathrm{Na}$ with $\mathrm{Ti}$ are indicative of similar input sources and/or a very close mineral association between these groups of elements. In addition, the highly positive correlation between Fe and Mn likely demonstrates the presence of $\mathrm{Fe} / \mathrm{Mn}$ compounds (augite, hornblende and goethite) in the investigated sediments. Negative correlations of both Ca and P with most of the major elements mark no preferred connection between these two elements with any others in Lake Dojran sediments (Table 3).

PCA (Fig. 5) explained $89.05 \%$ of data variance in the first two ordination axes. Samples from locations D1 and D2 were associated with the highest values of $\mathrm{Si}$ and $\mathrm{Al}$, whereas samples from locations D5 and D6 exhibited the highest values of $\mathrm{Fe}, \mathrm{Mg}, \mathrm{Mn}, \mathrm{Na}$ and Ti. P and Ca were defined in the sample obtained from location D4.

\subsection{Trace element concentrations of surficial lake sediments $(0-5 \mathrm{~cm})$}

Trace element concentrations ( $\mathrm{Au}, \mathrm{As}, \mathrm{Co}, \mathrm{Cr}, \mathrm{Cu}, \mathrm{Ni}, \mathrm{Pb}, \mathrm{Sb}$ and $\mathrm{Zn}$ ) and their mean, minimum, maximum and standard deviation values in Lake Dojran sediments are gathered in Table 4.

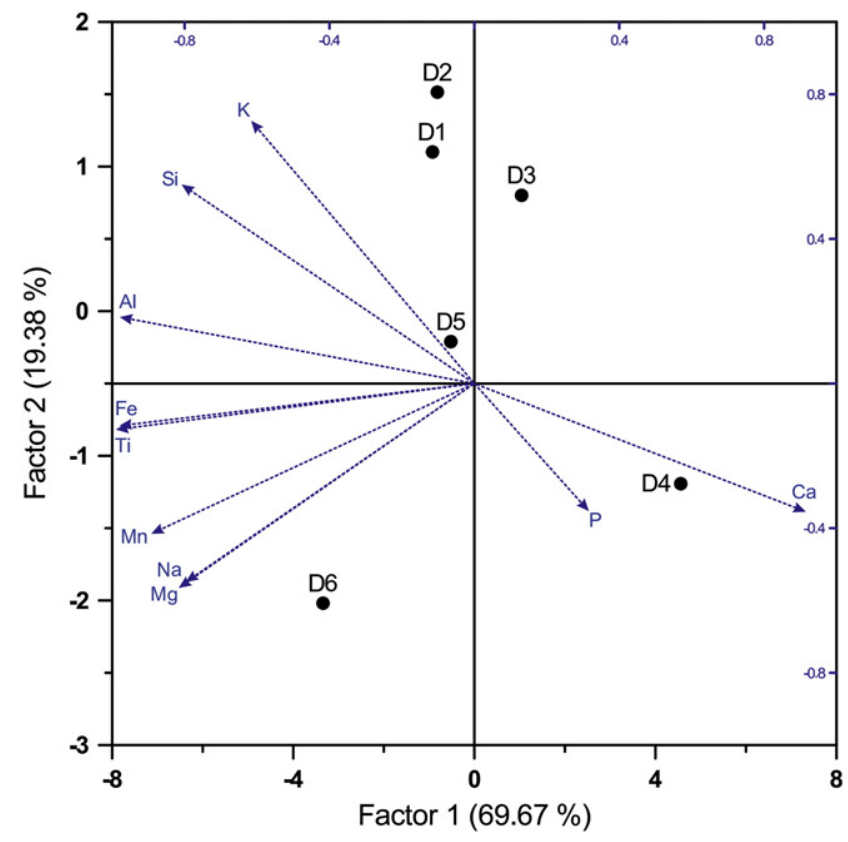

Fig. 5. Principal component analysis for major elements $(0-5 \mathrm{~cm}$ depth). 
Analysis revealed that mean sediment trace element concentrations increase in the following order: $\mathrm{Au}<\mathrm{Sb}<\mathrm{Cr}<\mathrm{Co}<\mathrm{Pb}<\mathrm{Cu}<\mathrm{As}<\mathrm{Ni}<\mathrm{Zn}$. The distribution of these trace elements was not uniform over the whole lake area, with concentrations higher in the $\mathrm{W}$ ( $\mathrm{As}, \mathrm{Cr}, \mathrm{Cu}, \mathrm{Ni}, \mathrm{Pb}, \mathrm{Sb}$ and $\mathrm{Zn}), \mathrm{N}(\mathrm{Co})$ and $\mathrm{SW}(\mathrm{Au})$. This pattern reflects high values connected with the sampling points D5 and D6, which are located closest to the city of Novi Dojran (Fig. 6).

Sediment EF values around or lower than 1.0 indicate that the element in question originates predominantly from crustal material and/or weathering processes (Zhang and Liu, 2002), whereas EF values much greater than 1.0 display the anthropogenic origin (Szefer et al., 1996). More recently, six contamination categories have been developed on the basis of enrichment factor values (Chen et al., 2007).

\begin{tabular}{ll}
\hline $\mathrm{EF}<3$ & Minor enrichment (anthropogenic impact) \\
$\mathrm{EF}=3-5$ & Moderate enrichment \\
$\mathrm{EF}=5-10$ & Moderately severe enrichment \\
$\mathrm{EF}=10-25$ & Severe enrichment \\
$\mathrm{EF}=25-50$ & Very severe enrichment \\
$\mathrm{EF}>50$ & Extremely severe enrichment \\
\hline
\end{tabular}

Enrichment factor calculations (Table 5) revealed $\mathrm{Cr}, \mathrm{Zn}, \mathrm{Pb}, \mathrm{Cu}$ and Co to exhibit the lowest EF values among the trace elements (mean values $0.2,1.33,1.53$ and 1.63 , respectively); these five elements are thus only minorly enriched in surficial sediments of Lake Dojran. Calculated $\mathrm{EF}$ values for $\mathrm{Ni}$, Au and $\mathrm{Sb}$ signified moderate enrichment (mean value 3.13) with $\mathrm{Ni}$, moderately severe enrichment (mean value 5.5) with Au and severe enrichment (mean value 11.2) with $\mathrm{Sb}$. As had the highest average EF value (32.5) among the representing trace elements with very severe enrichment in surficial sediments. The greatest overall EF values were determined in samples from locations D3 (Au), D5 (As, $\mathrm{Cr}, \mathrm{Cu}, \mathrm{Ni}, \mathrm{Pb}, \mathrm{Sb}$ and $\mathrm{Zn}$ ) and D6 (Co, Cu).

Particle size and density play important roles in determining the chemistry and ecology of sediments. The clay/silt fraction $(<63 \mu \mathrm{m})$ has a high specific surface area per unit quantity of material and, due to surface coatings of Fe and Mn elements and natural organic material, is more likely to adsorb organic and trace elements contaminants (Hart, 1982; Maher et al., 1999). Thus, most anthropogenic contaminants in Lake Dojran are associated with the confirmed clay (24.40\%) and silt (71.50\%) fractions (Stojanov et al., 1997). It can be concluded that the trace elements of Lake Dojran surficial sediments is derived from a number of different geogenic and anthropogenic sources. The geological background of the lake is generally dominated by metamorphic rocks (Stojanov and Micevski, 1989) which are composed of minerals that can contain trace elements in their structure, as well as polymetallic mineralization in basic rocks (Stojanov and Micevski, 1989) with arsenopyrite (FeAsS) and gold; these minerals all contribute to the enhanced levels of trace elements (especially As and $\mathrm{Au}$ ) found in lake sediments. Anthropogenic sources of trace elements include tourism activities taking place around the lake which result in increased traffic $(\mathrm{Pb})$ and coatings $(\mathrm{Sb})$, as well as urban inputs from the lake shore which discharge a large volume of wastewater, agrochemicals and landfill leachates from the nearest settlements. Solid and liquid wastes originating from urban areas are enriched with $\mathrm{Cu}, \mathrm{Pb}, \mathrm{Zn}$ and $\mathrm{Ni}$ (DVWK, 1998), while $\mathrm{Cu}, \mathrm{Pb}, \mathrm{Zn}, \mathrm{Cr}, \mathrm{Ni}$ and $\mathrm{Co}$ are also common constituents of many agrochemicals (Förstner and Wittmann, 1981). The spatial distribution of enrichment reflects the fact that sampling points D5 and D6 are located near the city of Novi Dojran and are in the vicinity of local hotel complexes.

Analysis via Pearson correlation matrix (Table 6) presented the following significantly positive correlations: As with $\mathrm{Pb}$; Co with $\mathrm{Zn}$ and $\mathrm{Ni}$; Cr with $\mathrm{Zn}$; Cu with $\mathrm{Pb}, \mathrm{Zn}$ and Ni; Ni with $\mathrm{Zn}$; and finally Sb with $\mathrm{Cr}$ and Ni. PCA (Fig. 7) accounted for $85.88 \%$ of data variance in the first two ordination axes, revealing highly significant positive correlations between $\mathrm{As}, \mathrm{Cr}, \mathrm{Pb}$ and $\mathrm{Sb}$ and between $\mathrm{Co}, \mathrm{Cu}, \mathrm{Ni}$ and $\mathrm{Zn}$ at locations D5 and D6, and highly negative correlation was again confirmed between $\mathrm{Au}$ (location D3) and other trace elements. These relationships likely demonstrate possible co-contamination from the aforementioned geogenic and anthropogenic sources. Conversely, no correlations were noted between $\mathrm{Au}$ and any other element, suggesting that the nature of Au contamination might be from a different source (e.g. polymetallic mineralization) (Olivares-Rieumont et al., 2005).

\subsection{Rare earth elements (REE) in surficial lake sediments $(0-5 \mathrm{~cm})$}

The total concentrations, as well as mean, minimum, maximum and standard deviation values, of REEs in Lake Dojran are presented in Table 7 (data regarding Pr, Gd, Dy, Ho, Er, Tm and Lu are not included since levels of these elements were under the detection limit). The mean RE elemental levels in the samples were slightly higher than those of the upper continental crust reported by Taylor and McLennan (1995) (Table 6). Light rare earth elements (LREEs) accounted for around $95 \%$ of total REE content in the investigated lake sediments, which is in agreement with Tyler (2004), indicating that LREEs are usually more abundant in sediments than are heavy rare earth elements (HREEs), just as in the Earth's crust. The highest detected values for all REEs were measured in the western and northern (Eu only) parts of the lake.

The concentration of individual REEs in sediments generally depends on their respective parent material (Zhu and Liu, 1988). The relatively high amounts of REEs observed in the present study can be attributed to the predominantly metamorphic and igneous lithologies (gneisses, shales, amphibolites, marbles, granite porphyries and Bjelasica granites) (Stojanov and Micevski, 1989) exposed in the Dojran region. Sediments derived from metamorphic and granitic rocks tend to have higher REE concentrations (Hu et al., 2006; Ure and Bacon, 1979), especially those originating from the latter rock type (Herman, 1970; Reiman and Caritat, 1998). In addition, among the essential minerals, salic minerals preferentially concentrate LREEs and femic minerals

Table 4

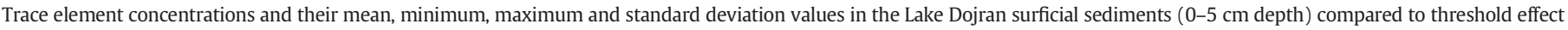
concentration (TEC) and probable effect concentration (PEC) (MacDonald et al., 2000).

\begin{tabular}{|c|c|c|c|c|c|c|c|c|c|}
\hline T. e. $(\mathrm{mg} / \mathrm{kg}) /$ sample & $\mathrm{Au}$ & As & Co & $\mathrm{Cr}$ & $\mathrm{Cu}$ & $\mathrm{Ni}$ & $\mathrm{Pb}$ & $\mathrm{Sb}$ & $\mathrm{Zn}$ \\
\hline D1 & 0.005 & 42.00 & 20.00 & 7.30 & 41.00 & 59.00 & 27.00 & 2.40 & 102.00 \\
\hline D2 & 0.005 & 36.00 & 19.00 & 7.00 & 31.00 & 55.00 & 20.00 & 2.00 & 94.00 \\
\hline D3 & 0.016 & 45.00 & 14.00 & 5.40 & 22.00 & 37.00 & 21.00 & 1.80 & 74.00 \\
\hline D4 & 0.006 & 30.00 & 9.00 & 3.40 & 18.00 & 27.00 & 16.00 & 1.20 & 46.00 \\
\hline D5 & 0.006 & 57.00 & 20.00 & 8.10 & 54.00 & 70.00 & 46.00 & 2.70 & 109.00 \\
\hline D6 & 0.005 & 40.00 & 30.00 & 5.20 & 43.00 & 75.00 & 28.00 & 1.30 & 105.00 \\
\hline Mean & 0.008 & 41.70 & 18.70 & 6.10 & 34.80 & 53.80 & 26.30 & 1.90 & 88.30 \\
\hline Min & 0.005 & 30.00 & 9.00 & 3.40 & 18.00 & 27.00 & 16.00 & 1.20 & 46.00 \\
\hline Max & 0.016 & 57.00 & 30.00 & 8.10 & 54.00 & 75.00 & 46.00 & 2.70 & 109.00 \\
\hline Std. dev. & 0.005 & 9.10 & 7.00 & 1.70 & 13.70 & 18.70 & 10.60 & 0.60 & 24.20 \\
\hline TEC & / & 9.79 & / & 43.40 & 31.60 & 22.70 & 35.80 & / & 121.00 \\
\hline PEC & / & 33.00 & / & 111.00 & 149.00 & 48.60 & 128.00 & I & 149.00 \\
\hline
\end{tabular}



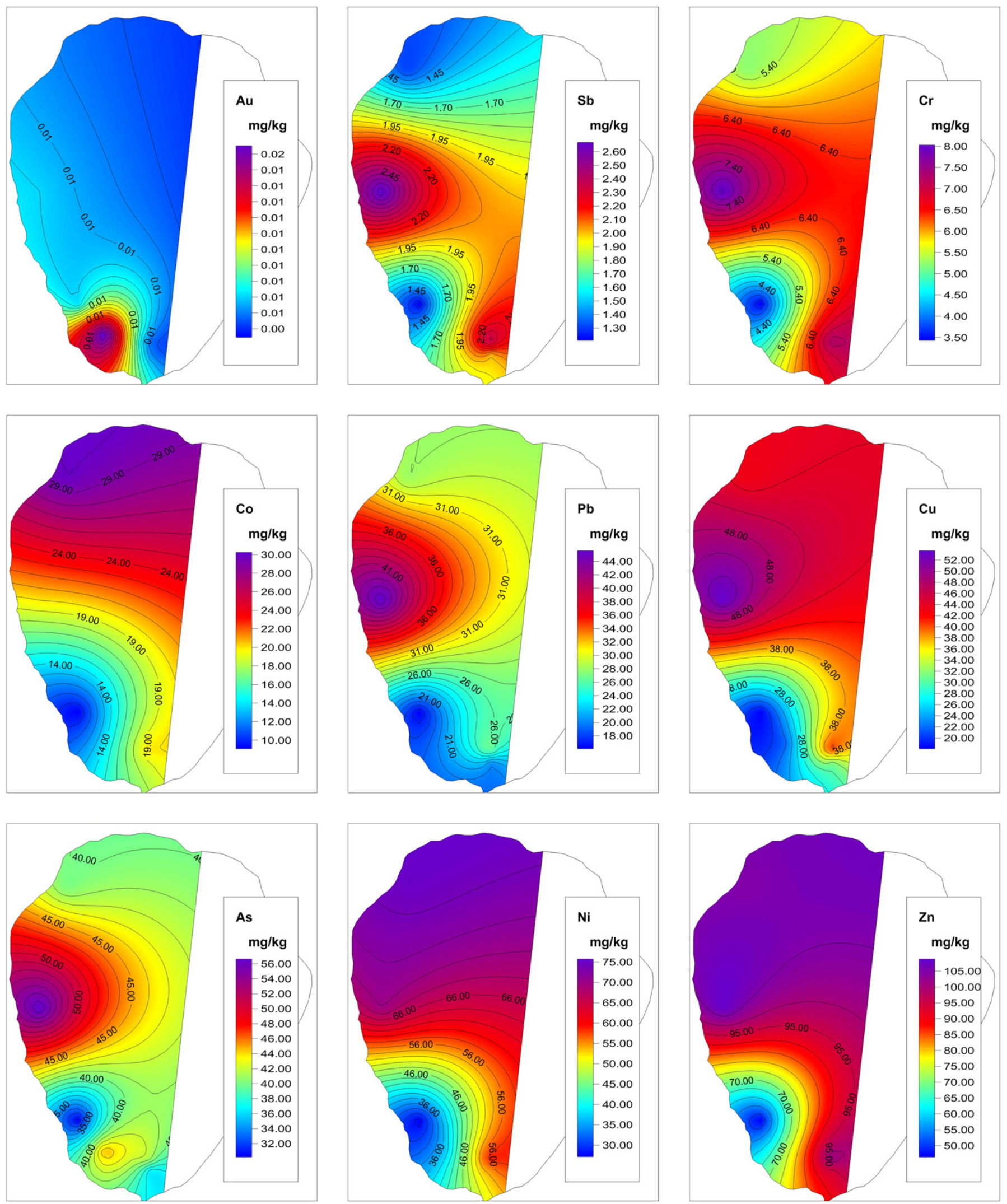

Fig. 6. Spatial distribution of trace elements $(0-5 \mathrm{~cm}$ depth).

HREEs. The preferential decomposition of femic minerals and calcic plagioclases compared with that of the more resistant sodic and potassium feldspars during weathering (Laveuf et al., 2009) of the exposed lithologies in the Dojran region likely resulted in the enrichment of HREEs in lake sediments. Amphiboles identified in Lake Dojran sediments can be considered another source of HREE enrichment (Laveuf et al., 2009), while sediment REE content could also be affected and thus enriched by various anthropogenic inputs such as manure, phosphate 
Table 5

Calculated enrichment factor for trace elements ( $0-5 \mathrm{~cm}$ depth).

\begin{tabular}{lrrrc}
\hline & Mean & Min & Max & Std. dev. \\
\hline $\mathrm{Au}$ & 5.46 & 2.53 & 11.94 & 4.03 \\
$\mathrm{As}$ & 35.43 & 24.21 & 54.54 & 11.96 \\
$\mathrm{Co}$ & 2.19 & 1.88 & 2.74 & 0.34 \\
$\mathrm{Cr}$ & 0.21 & 0.13 & 0.27 & 0.045 \\
$\mathrm{Cu}$ & 1.66 & 1.18 & 2.31 & 0.43 \\
$\mathrm{Ni}$ & 3.20 & 2.49 & 3.75 & 0.51 \\
$\mathrm{~Pb}$ & 1.62 & 1.01 & 2.47 & 0.57 \\
$\mathrm{Sb}$ & 11.86 & 5.93 & 16.36 & 3.62 \\
$\mathrm{Zn}$ & 1.49 & 1.33 & 1.77 & 0.17 \\
\hline
\end{tabular}

fertilizers and waste effluent (Protano and Riccobono, 2002; Wang et al., 2004).

Correlation analysis (Table 8) revealed (1) highly significant correlations between elements from the LREE group and (2) highly significant correlations between HREEs and Sm. These findings are indicative of similar input sources, confirming the common geochemical characteristics of the REEs and the abovementioned results.

\subsection{Surficial sediment geochemistry (5-10 and 10-15 cm depth)}

Total elemental concentrations in Lake Dojran surficial sediments (5-10 and $10-15 \mathrm{~cm}$ ) are listed in Table 9.

Table 6

Pearson correlation coefficient between trace elements $(0-5 \mathrm{~cm}$ depth $)$.

\begin{tabular}{|c|c|c|c|c|c|c|c|c|c|}
\hline & \multicolumn{9}{|c|}{ Marked correlation are significant at $\mathrm{p}<0.05$} \\
\hline & $\mathrm{Au}$ & As & Co & $\mathrm{Cr}$ & $\mathrm{Sb}$ & $\mathrm{Cu}$ & $\mathrm{Pb}$ & $\mathrm{Zn}$ & $\mathrm{Ni}$ \\
\hline $\mathrm{Au}$ & 1.00 & 0.20 & -0.39 & -0.21 & -0.08 & -0.47 & -0.21 & -0.34 & -0.48 \\
\hline As & 0.20 & 1.00 & 0.30 & 0.72 & 0.76 & 0.73 & 0.90 & 0.64 & 0.55 \\
\hline Co & -0.39 & 0.30 & 1.00 & 0.39 & 0.11 & 0.72 & $\overline{0.45}$ & 0.84 & 0.92 \\
\hline $\mathrm{Cr}$ & -0.21 & 0.72 & 0.39 & 1.00 & 0.94 & 0.76 & 0.71 & $\overline{0.83}$ & $\overline{0.65}$ \\
\hline $\mathrm{Sb}$ & -0.08 & 0.76 & 0.11 & 0.94 & $\overline{1.00}$ & 0.65 & 0.70 & $\overline{0.63}$ & 0.42 \\
\hline $\mathrm{Cu}$ & -0.47 & 0.73 & 0.72 & $\overline{0.76}$ & 0.65 & 1.00 & 0.91 & 0.90 & 0.92 \\
\hline $\mathrm{Pb}$ & -0.21 & 0.90 & 0.45 & 0.71 & 0.70 & 0.91 & $\overline{1.00}$ & $\overline{0.72}$ & $\overline{0.72}$ \\
\hline $\mathrm{Zn}$ & -0.34 & $\overline{0.64}$ & 0.84 & 0.83 & 0.63 & $\overline{0.90}$ & 0.72 & 1.00 & 0.95 \\
\hline $\mathrm{Ni}$ & -0.48 & 0.55 & $\overline{0.92}$ & $\overline{0.65}$ & 0.42 & $\overline{0.92}$ & 0.72 & 0.95 & $\overline{1.00}$ \\
\hline
\end{tabular}

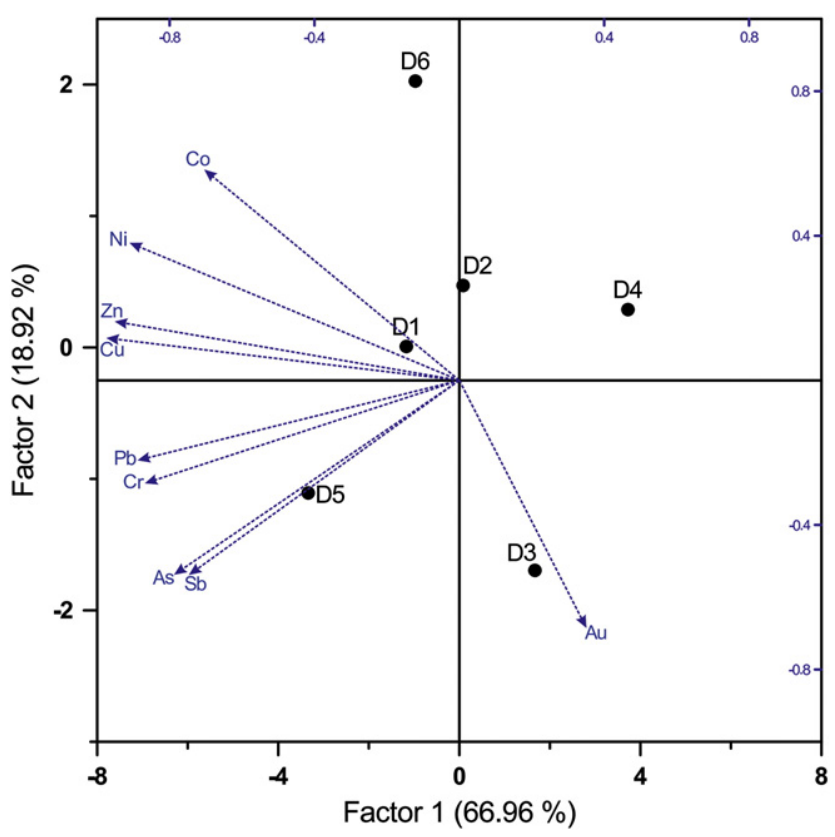

Fig. 7. Principal component analysis for trace elements (0-5 cm depth).
Table 7

Total REE concentrations in the surficial sediments $(0-5 \mathrm{~cm}$ depth) from Lake Dojran with descriptive statistics plus results from (A) upper continental crust (Taylor and McLennan, 1995).

\begin{tabular}{llllrlll}
\hline REE $(\mathrm{mg} / \mathrm{kg}) / \mathrm{sample}$ & $\mathrm{La}$ & $\mathrm{Ce}$ & $\mathrm{Nd}$ & $\mathrm{Sm}$ & $\mathrm{Eu}$ & $\mathrm{Tb}$ & $\mathrm{Yb}$ \\
\hline D1 & 37.00 & 73.00 & 29.00 & 5.80 & 1.00 & 0.70 & 2.60 \\
D2 & 33.10 & 66.00 & 26.00 & 5.30 & 1.00 & 0.70 & 2.50 \\
D3 & 48.50 & 95.00 & 40.00 & 7.60 & 1.30 & 0.60 & 2.70 \\
D4 & 28.80 & 60.00 & 22.00 & 5.10 & 0.60 & 0.50 & 2.00 \\
D5 & 61.90 & 125.00 & 51.00 & 11.90 & 1.40 & 1.40 & 5.00 \\
D6 & 34.50 & 67.00 & 34.00 & 8.10 & 1.60 & 1.00 & 4.40 \\
Mean & 40.6 & 81.0 & 33.7 & 7.3 & 1.1 & 0.8 & 3.2 \\
Min & 28.8 & 60.0 & 22.0 & 5.1 & 0.6 & 0.5 & 2.0 \\
Max & 61.9 & 125.0 & 51.0 & 11.9 & 1.6 & 1.4 & 5.0 \\
Std. dev. & 12.3 & 24.7 & 10.6 & 2.6 & 0.4 & 0.3 & 1.2 \\
A & 30 & 64 & 26 & 4.5 & 0.88 & 0.64 & 2.2 \\
\hline
\end{tabular}

The abundances of the major elements were almost constant throughout depth $(5-15 \mathrm{~cm})$, with $\mathrm{Ca}, \mathrm{Na}, \mathrm{Mn}$ and $\mathrm{P}$ concentrations slightly increasing up and those of $\mathrm{Si}, \mathrm{Al}, \mathrm{Fe}, \mathrm{Mg}$, $\mathrm{K}$ and Ti slightly decreasing up. No significant difference was detected regarding element spatial distribution patterns (samples D3 C and D6 C).

Trace element concentrations ( $\mathrm{Au}, \mathrm{As}, \mathrm{Co}, \mathrm{Cr}$ and $\mathrm{Sb}$ ) were also generally constant, both throughout surficial sediment depth and spatially across the lake (samples D3 C and D6 C). However, while levels of Pb, $\mathrm{Cu}, \mathrm{Zn}$ and $\mathrm{Ni}$ in sample D6 $\mathrm{C}$ again displayed a constant pattern, those of sample D3 C decreased up. Site D3 C is located near Stari Dojran, which was the major urban center and tourist attraction on Lake Dojran twenty years ago. The data obtained from the D3 C sample therefore indicate the higher anthropogenic inflow of trace element around the Stari Dojran area. Rare earth element concentrations slightly increased with depth, while no spatial difference was observed between the studied samples.

Enrichment factor values calculated for trace elements revealed minor to very severe enrichment of Lake Dojran surficial sediments.

\subsection{Lake Dojran sediment (e.g. peloids) potentials for application in} balneotherapy

To be convenient for balneotherapy use, peloids mineralogical and chemical composition controls are necessary, especially trace element content. The abundance of trace element in peloids is very important, because of their potential hazardous effects on health; high concentrations of trace element can provoke some seriously health diseases (Miko et al., 2008; Rebelo et al., 2011; Tateo et al., 2009; Veniale et al., 2007; Vreča and Dolenec, 2005).

Unfortunately, there is still no official regulations and standards about chemical composition of peloids, used for raw material in balneotherapy. Therefore, the obtained results were compared to consensus-based sediment quality guidelines (SQGs) defined by MacDonald et al. (2000). The SQG values such as the threshold effect concentration (TEC) and probable effect concentration (PEC) provide a reliable basis for assessing sediment quality conditions in aquatic ecosystems. The TEC value for a particular element represents a concentration below which harmful effects are unlikely to be observed, while PEC

Table 8

Pearson correlation coefficient between REE elements (0-5 cm depth).

\begin{tabular}{|c|c|c|c|c|c|c|c|}
\hline & \multicolumn{7}{|c|}{ Marked correlation are significant at $\mathrm{p}<0.05$} \\
\hline & La & $\mathrm{Ce}$ & $\mathrm{Nd}$ & $\mathrm{Sm}$ & $\mathrm{Eu}$ & $\mathrm{Tb}$ & $\mathrm{Yb}$ \\
\hline La & 1.00 & 1.00 & 0.97 & 0.89 & 0.54 & 0.72 & 0.66 \\
\hline $\mathrm{Ce}$ & 1.00 & $\overline{1.00}$ & $\overline{0.95}$ & $\overline{0.89}$ & 0.49 & 0.72 & 0.65 \\
\hline $\mathrm{Nd}$ & $\overline{0.97}$ & 0.95 & $\overline{1.00}$ & $\overline{0.96}$ & 0.73 & 0.80 & 0.80 \\
\hline $\mathrm{Sm}$ & $\overline{0.89}$ & $\overline{0.89}$ & 0.96 & $\overline{1.00}$ & 0.72 & 0.91 & 0.91 \\
\hline $\mathrm{Eu}$ & $\overline{0.54}$ & $\overline{0.49}$ & $\overline{0.73}$ & 0.72 & 1.00 & $\overline{0.69}$ & $\overline{0.83}$ \\
\hline $\mathrm{Tb}$ & 0.72 & 0.72 & 0.80 & 0.91 & 0.69 & 1.00 & $\overline{0.96}$ \\
\hline $\mathrm{Yb}$ & 0.66 & 0.65 & 0.80 & $\overline{0.91}$ & 0.83 & 0.96 & $\overline{1.00}$ \\
\hline
\end{tabular}


Tables 9

The total elemental contents in the surficial 5-10 and 10-15 cm depths of Lake Dojran sediments.

\begin{tabular}{lllllllllll}
\hline El. $(\mathrm{g} / \mathrm{kg}) / \mathrm{sample}$ & $\mathrm{Si}$ & $\mathrm{Al}$ & $\mathrm{Fe}$ & $\mathrm{Ca}$ & $\mathrm{Mg}$ & $\mathrm{K}$ & $\mathrm{Na}$ & $\mathrm{Mn}$ & $\mathrm{P}$ & $\mathrm{Ti}$ \\
\hline D3 B & 217.0 & 71.7 & 34.3 & 0.70 & 8.0 & 94.2 & 8.4 & 18.1 & 2.9 & 1.5 \\
D3 C & 195.1 & 70.5 & 34.4 & 0.64 & 8.1 & 117.1 & 7.2 & 18.4 & 2.8 & 1.6 \\
D6 B & 248.8 & 87.1 & 59.2 & 1.07 & 20.3 & 38.8 & 20.6 & 14.2 & 4.4 & 0.9 \\
D6 C & 244.1 & 89.3 & 59.8 & 1.20 & 19.4 & 34.02 & 18.0 & 16.4 & 4.4 & 1.1 \\
& & & & & & & & & \\
T. e. $(\mathrm{mg} / \mathrm{kg}) / \mathrm{sample}$ & $\mathrm{Au}$ & $\mathrm{As}$ & $\mathrm{Co}$ & $\mathrm{Cr}$ & $\mathrm{Cu}$ & $\mathrm{Ni}$ & $\mathrm{Pb}$ & $\mathrm{Sb}$ & $\mathrm{Zn}$ \\
\hline D3 B & 0.015 & 35 & 18 & 6.7 & 62 & 52 & 43 & 2.7 & 93 \\
D3 C & 0.013 & 30 & 17 & 8.5 & 62 & 54 & 42 & 2.7 & 97 \\
D6 B & 0.005 & 36 & 27 & 4.4 & 45 & 72 & 31 & 1.5 & 105 \\
D6 C & 0.005 & 45 & 28 & 6.6 & 45 & 72 & 28 & 1.6 & 109 \\
& & & & & & & & & \\
REE (mg/kg)/sample & $\mathrm{La}$ & $\mathrm{Ce}$ & & $\mathrm{Nd}$ & $\mathrm{Sm}$ & $\mathrm{Eu}$ & $\mathrm{Tb}$ & $\mathrm{Yb}$ \\
\hline D3 B & 50.60 & 98.00 & 38.00 & 9.00 & 1.30 & 0.90 & 3.70 \\
D3 C & 50.70 & 96.00 & 40.00 & 8.80 & 1.30 & 1.00 & 3.60 \\
D6 B & 34.60 & 68.00 & 32.00 & 8.30 & 1.60 & 0.90 & 4.40 \\
D6 C & 43.50 & 86.00 & 44.00 & 9.60 & 1.60 & 1.30 & 4.70 \\
\hline
\end{tabular}

values are used to identify contaminant concentrations above which harmful effects to benthic organisms are expected to occur frequently (MacDonald et al., 2000). Comparison of sediment trace element concentrations with the consensus-based TEC and PEC values (Table 4) revealed the following: (1) In Lake Dojran sediments the mean concentration of $\mathrm{Cu}$ is higher than the recommended TEC value and (2) the mean concentrations of As and $\mathrm{Ni}$ are higher than both the TEC and PEC special values. As a result, the biota of Lake Dojran may currently be in danger of being contaminated with these three elements.

Given these results, Lake Dojran dark mud sediments (peloids) cannot be recommended/confirmed for use in balneotherapeutic treatments since there is increasing evidence that the trace element contamination of virgin material (e.g. dark mud sediments/peloids) can seriously damage the health of users (Carretero, 2002; Mascolo et al., 1999, 2004; Miko et al., 2008; Rebelo et al., 2011; Summa and Tateo, 1998; Tateo et al., 2009; Veniale et al., 2007). As a result, future analysis of these sediments will focus on the mobility and bioavailability of trace elements.

\section{Conclusions}

In the present study the mineralogical and geochemical properties of Lake Dojran surficial sediments were examined in detail.

Mineralogical analysis revealed that the lake's surficial and core sediment mineralogy is closely related to the prevailing metamorphic, volcanic and igneous rocks of the Dojran region. The mineralogical assemblage of lake sediments is mostly composed of quartz, feldspars, clay minerals, calcite and micas, along with minor amounts of augite and hornblende.

More than $65 \%$ of major elements in almost all samples were accounted for $\mathrm{Si}-\mathrm{Al}-\mathrm{Fe}$ components, reflecting a relatively high proportion of quartz, feldspars, clay minerals and micas present in surficial lake sediments $(0-5,5-10,10-15 \mathrm{~cm})$. The CIA values of around $67 \%$ of the samples suggest that the lake catchment area undergoes moderate degree of weathering. Mean trace element concentrations in Lake Dojran sediments increase in the following order: $\mathrm{Au}<\mathrm{Sb}<\mathrm{Cr}<\mathrm{Co}<\mathrm{Pb}<$ $\mathrm{Cu}<\mathrm{As}<\mathrm{Ni}<\mathrm{Zn}$. According to calculated $\mathrm{EF}$ values, surficial Lake Dojran sediments $(0-5 \mathrm{~cm})$ are little enriched with $\mathrm{Cr}, \mathrm{Zn}, \mathrm{Pb}, \mathrm{Cu}$ and $\mathrm{Co}$, moderately enriched with $\mathrm{Ni}, \mathrm{Au}$ and $\mathrm{Sb}$, moderately severely enriched with $\mathrm{Au}$, severely enriched with $\mathrm{Sb}$ and very severely enriched with As. The abovementioned enrichment originates from a number of different geogenic (geological background and polymetallic mineralization with arsenopyrite (FeAsS) and gold ( $\mathrm{Au})$ ) and anthropogenic sources. The latter include various tourism activities which take place around the lake - and the associated increase in traffic $(\mathrm{Pb})$ and coatings $(\mathrm{Sb})-\mathrm{as}$ well as urban inputs from the lake shore which discharge a considerable volume of wastewater, agrochemicals and landfill leachates. The relatively high amounts of REEs can be assigned to the Dojran region's predominantly metamorphic and igneous lithologies (gneisses, shales, amphibolites, marbles, granite porphyries and Bjelasica granites). The abundances of the major elements, trace elements and REEs were almost constant throughout the surficial sediments depth, except $\mathrm{Pb}$, $\mathrm{Cu}, \mathrm{Zn}$ and Ni values in sample D3 C increased with depth $(0-15 \mathrm{~cm})$, indicating higher anthropogenic inflow of trace element in the area of the city of Stari Dojran.

Comparison of the abovementioned concentrations with the consensus-based TEC and PEC values showed that the average concentration of $\mathrm{Cu}$ in Lake Dojran sediments is higher than recommended TEC values, while those of As and Ni are higher than both TEC and PEC special values. These results define that the lake biota may be in danger of being contaminated with $\mathrm{Cu}$, $\mathrm{As}$ and $\mathrm{Ni}$. Considering the results, the use of Lake Dojran dark muds (peloids) for various balneotherapeutic treatments cannot be recommended. Future research will involve analysis of the mobility and bioavailability of trace elements in these sediments.

\section{Acknowledgments}

This study was financially supported by the ARRS Programme group P1-0195 (Geochemical and structural processes) and the COST Action TD0903 project: Understanding and manipulating enzymatic and proteomic processes in biomineralization.

\section{References}

Arnason, J.G., Fletcher, B.A., 2003. A $40+$ year record of Cd, Hg, Pb and U deposition in sediments of Patroon Reservoir, Albany County, NY, USA. Environ. Pollut. 123, 383-391.

Aysegül, K., Balkis, N., Erkan, M., Balkais, H., Aksu, A., Ersan, M.S., 2010. Total metal levels in crayfish Astacus leptodactylus (Escholtz, 1823), and surface sediments in Lake Terkos, Turkey. Environ. Monit. Assess. 169, 358-395.

Bibi, M.H., Ahmed, F., Ishiga, H., 2007. Assessment of metal concentrations in lake sediments of southwest Japan based on sediment quality guidelines. Environ. Geol. 52 625-639.

Carretero, M.I., 2002. Clay minerals and their beneficial effects upon human health. A review. Appl. Clay Sci. 21, 155-163.

Chen, C.W., Kao, C.M., Chen, C.F., Dong, C.D., 2007. Distribution and accumulation of heavy metals the sediments of Kaohsiung Harbor, Taiwan. Chemosphere 66 (8) 1431-1440.

Demirak, A., Yilmaz, F., Levent, Tuna, A., Ozdemir, N., 2006. Heavy metals in water, sediment and tissues of Leuciscus cephalus from a stream in southwestern Turkey. Chemosphere 63, 1451-1458.

DVWK (Deutsche Verband für Wasserwirtschaft und Kulturbau e.V.), 1998 Hydrogeochemische Stoffsysteme, Heft 117, Teil II.

Fan, C.X., Zhu, Y.X., Ji, Z.J., Zhang, L., Yang, L.Y., 2002. Characteristics of the pollution of heavy metals the sediments of Yilihe River, Taihu Basin. J. Lake Sci. 14 (3), 235-241.

Förstner, U., Wittmann, G.T.W., 1981. Metal Pollution in the Aquatic Environment. Springer, Berlin, Heidelberg, New York.

Ghrefat, H., Yusuf, N., 2006. Assessing Mn, Fe, Cu, Zn, and Cd pollution in bottom sediments of Wadi Al-Arab Dam, Jordan. Chemosphere 65, 2114-2121.

Gramatica, P., Battaini, F., Giani, E., Papa, E., Jones, R.J.A., Preatoni, D., Cenci, R.M., 2006. Analysis of mosses and soils for quantifying heavy metal concentrations in Sicily: a multivariate and spatial analytical approach. Environ. Sci. Pollut. Res. 13, 28-36.

Hart, B.T., 1982. Uptake of trace metals by sediments and suspended particulates: a review. Hydrobiologia 91, 299-313.

Herman, A.G., 1970. Yttrium and Lanthanides. In: Wedepohl, K.H. (Ed.), Handbook of Geochemistry. Springer-Verlag, Berlin, pp. 57-71.

Hu, Z., Haneklaus, S., Sparovek, G., Schnug, E., 2006. Rare earth elements in soils. Commun. Soil Sci. Plant Anal. 37 (9-10), 1381-1420.

Kabata-Pendias, A., Pendias, H., 2001. Trace Elements in Soils and Plants. 3rd ed. CRC Press, Boca Raton, FL

Karakaya, M.C., Muazzez, C., Karakaya, N., Sarioglan, S., 2010. Some properties of thermal muds of some spas in Turkey. Appl. Clay Sci. 48, 531-537.

Kemp, A.L.W., Thomas, R.L., Dell, C.I., Jaquet, J.M., 1976. Cultural impact on the geochemistry of sediments in Lake Erie. Can. J. Fish. Aquat. Sci. 33, 440-485.

Khaled, A., El Nemr, A., El Sikaily, A., 2006. An assessment of heavy-metal contamination in surface sediments of the Suez Gulf using geoaccumulation indexes and statistical analysis. Chem. Ecol. 22 (3), 239-252.

Kumar Das, S., Routh, J., Roychoudhury, A.N., Val Klump, J., 2008. Major and trace element geochemistry in Zeekoevlei, South Africa: a lacustrine record of present and past processes. Appl. Geochem. 23, 2496-2511. 
Laveuf, C., Cornu, S., 2009. A review on the potentiality of rare earth elements to trace pedogenetic processes. Geoderma 154, 1-12.

MacDonald, D.D., Ingersoll, G., Berger, T.A., 2000. Development and evaluation of consensus-based sediment quality guidelines for freshwater ecosystems. Arch. Environ. Contam. Toxicol. 39, 20-31.

Maher, W., Batkey, G.E., Lawrence, I., 1999. Assessing the health of sediment ecosystems: use of chemical measurements. Freshw. Biol. 41, 361-372.

Maltby, E., 1992. Soil and Wetland Functions. In: Gerakis, P.A. (Ed.), Conservation and Management of Greek Wetlands. The IUCN Wetlands Programme, pp. 9-60.

Mascolo, N., Stumma, V., Tateo, F., 1999. Characterization of toxic elements in clays for human healing use. Appl. Clay Sci. 15, 491-500.

Mascolo, N., Stumma, V., Tateo, F., 2004. In vivo experimental data on the mobility of hazardous chemical elements from clays. Appl. Clay Sci. 25, 23-28.

McLennan, S.E., 1993. Evolution of the Earth's surface. J. Geol. 101 (2), 295-303.

Miko, S., Koch, G., Mesič, S., Šparica-Miko, M., Šparica, M., Čepelak, R., Bačani, A., Vreča, P. Dolenec, T., Bergant, S., 2008. Anthropogenic influence on trace element geochemistry of healing mud (peloid) from Makirina Cove (Croatia). Environ. Geol. 55, 517-537.

Nesbitt, H.W., Young, G.M., 1982. Early Proterozoic climates and plate motions inferred from major element chemistry of lutites. Nature 299, 715-717.

Olivares-Rieumont, S., Rosa, D., Lima, L., Graham, D.W., Alessandro, K.D., Borroto, J., Martínez, F., Sánchez, J., 2005. Assessment of heavy metal levels in Almendares River sediments-Havana City, Cuba. Water Resour. 39, 3945-3953.

Oyewale, A.O., Musa, I., 2006. Pollution assessment of the lower basin of Lakes Kainji/ Jebba, Nigeria: heavy metal status of the waters, sediments and fishes. Environ. Geochem. Health 28, 273-281.

Protano, G., Riccobono, F., 2002. High contents of rare earth elements (REEs) in stream waters of a $\mathrm{Cu}-\mathrm{Pb}-\mathrm{Zn}$ mining area. Environ. Pollut. 117, 499-514.

Rebelo, M., Viseras, C., López-Galindo, A., Rocha, F., Ferreira da Silva, E., 2011. Characterization of Portuguese geological materials to be used in medical hydrology. Appl. Clay Sci. 51, 258-266.

Reiman, C., Caritat, P., 1998. Chemical Elements in the Environment, Ed. Springer-Verlag, Berlin.

Singh, K.P., Mohan, D., Singh, V.K., Malik, A., 2005. Studies on distribution and fractionation of heavy metals Gomti river sediments - a tributary of the Ganges. J. Hydrol. $312,14-27$.
Stojanov, R., Micevski, E., 1989. Geologija na Dojransko Ezero I negovata okolina. Prilozi 10 (1-2), 35/37.

Stojanov, R., Obradović, J., Djurić, S., 1997. Dojran Lake dark mud. Symposium - annual meeting (Dojran-Štip). Faculty of Mining and, Geology, pp. 221-225.

Summa, V., Tateo, F., 1998. The use of pelitic raw materials in thermal centres: mineralogy, geochemistry, grain size and leaching tests. Examples from the Lucania area (southern Italy). Appl. Clay Sci. 12, 403-417.

Szefer, P. Glasby, G.P., Szefer, K., Pempkowiak, J., Kaliszan, R, 1996. Heavy-metal pollution in superficial sediments from the southern Baltic Sea of Poland. J. Environ. Sci. Health 31A, 2723-2754.

Tateo, F., Ravaglioli, A., Andreoli, C., Bonina, F., Coiro, V., Degetto, S., 2009. The in vitro percutaneous migration of chemical elements from a thermal mud for healing use. Appl. Clay Sci. 44, 83-94.

Taylor, S.R., McLennan, S.M., 1995. The geochemical evaluation of the continental crust. Rev. Geophys. 33, 241-265.

Tyler, G., 2004. Rare earth elements in soil and plant systems - a review. Plant Soil 267 (1-2), 191-206

Tylmann, W., Lysek, K., Kinder, M., Pempkowiak, J., 2011. Regional pattern of heavy metal content in lake sediments in northern Poland. Water Air Soil Pollut. 216, 217-228.

Ure, A.M., Bacon, J.R., 1979. Comprehensive analyses of soils and rocks by spark-source mass spectrometry. Analyst 103-807.

Van Metre, P.C., Callender, E., 1997. Water quality trends in White Rock Creek basin from 1912-1994 identified using sediment cores from White Rock Lake reservoir, Dallas, Texas. J. Paleolimnol. 17, 239-249.

Veniale, F., Bettero, A., Jobstraibizer, P.G., Setti, M., 2007. Thermal muds: perspectives of innovations. Appl. Clay Sci. 36, 141-147.

Vreča, P., Dolenec, T., 2005. Geochemical estimation of copper contamination in the healing mud from Makirina Bay, central Adriatic. Environ. Int. 31, 53-61.

Wang, Y., Wang, J., Wang, L., Wang, Y., Tu, C., 2004. REE characteristics of the Kalatongke Cu-Ni Deposit, Yinjiang, China. Acta Geol. Sin. 78, 396-403.

Zhang, J., Liu, C.L., 2002. Riverine composition and estuarine geochemistry of particulate metals in China - weathering features, anthropogenic impact and chemical fluxes. Estuar. Coast. Shelf Sci. 54, 1051-1070.

Zhu, Q.Q., Liu, Z., 1988. REEs in soils of eastern China. J. Chin. Rare Earth Soc. (in Chinese) 6 (4), 59-65. 